\title{
O Império da Opinião: Espaço Público, Opinião Pública e a Legitimidade do Político no Argumento Liberal
}

\author{
Paulo Cassimiro \\ Instituto de Estudos Sociais e Políticos da Universidade do Estado do Rio de Janeiro \\ (IESP-UERJ), Rio de Janeiro, RJ, Brasil. (e-mail: phpcassimiro@gmail.com)
}

\section{INTRODUÇÃO: O ARGUMENTO LIBERAL E A INVENÇÃO DA LEGITIMIDADE PÓS-REVOLUCIONÁRIA.}

\begin{abstract}
s noções de opinião pública e espaço público são centrais nas teoA rias democráticas: encontramo-nas no seminal estudo de Jürgen Habermas, Transformação Estrutural da Esfera Pública, publicado originalmente em 1962, no qual o autor traça uma história filosófica de ambos os problemas e sua relação com a constituição de uma ordem pública moderna; na existência de uma opinião pública como um dos requisitos centrais da liberdade negativa segundo a caracterização de Isaiah Berlin; na relação entre opinião pública e razão pública como fundamento de consensos democráticos na teoria liberal de John Rawls; na caracterização de Bernard Manin da opinião pública como uma contraparte democrática ao elemento não democrático essencialmente vinculado ao governo representativo; nas leituras como a de Nadia Urbinati, que apresentam a democracia como uma "diarquia" dividida entre os procedimentos institucionais do governo representativo e a opinião pública como esfera da participação e da avaliação do poder por parte dos cidadãos ${ }^{1}$. Em todas as interpretações, os problemas inerentes à prática da opinião pública não são ignorados: o acesso restrito aos mecanismos de expressão por parte de grupos minoritários, o monopólio da imprensa e a relação entre interesses econômicos e informação, as distorções produzidas pelos mediadores entre a infor-

DADOS - Revista de Ciências Sociais, Rio de Janeiro, vol. 61, no-3, 2018, pp. 659 a 693.
\end{abstract}

http://dx.doi.org/10.1590/001152582018170

659 
mação e o público, etc. Em todos os casos, contudo, a existência de uma esfera na qual opiniões se confrontam e se traduzem em escolhas eleitorais e em mobilização política é reputada essencial para a manutenção da democracia e para a construção de consensos democráticos.

A percepção do nascimento de uma esfera na qual a soberania do indivíduo-cidadão se exerce para além do mecanismo institucional do voto e na qual se confundiriam a dimensão privada das visões de mundo e dos interesses (entendidos como expressão de vontades particulares) e a construção de consensos sobre o bem comum e avaliação dos representantes é inseparável da constituição do liberalismo como linguagem política central para a democracia como forma de sociedade e de governo. Se é verdade que a questão fundamental da imaginação política liberal é a busca pela solução do problema da limitação legítima do poder, a república moderna será pensada pelos liberais como um sutil e complexo sistema de equilíbrio e limitação dos poderes essenciais à preservação das garantias fundamentais do indivíduo-cidadão, dentre as quais se encontra a sua autodeterminação em uma esfera constituída fora do Estado, na qual se confundem a dimensão das trocas e do interesse privado e a dimensão da opinião pública: a sociedade civil.

O contexto da Revolução Francesa (1789-1799) pode ser tomado como um momento exemplar da formação das concepções centrais que dariam forma a uma "linguagem liberal". A linguagem moderna do liberalismo francês começa a emergir durante o Diretório (1794) e se estende pelo período do Império (1804-1814) para consolidar-se na Restauração (1814-1848), quando se tornará o principal instrumental do debate constitucional, buscando a transação possível entre Revolução e Antigo Regime. A crise do período do Terror, encerrado em 1794 com a dissolução do Comitê de Salvação Pública e a morte de Robespierre e de vários de seus aliados, abre espaço para uma série de formulações teórico-constitucionais sobre a possibilidade de superação do modelo radical da república jacobina, centrado nas ideias de soberania do povo e estado de exceção ${ }^{2}$. Ele seria substituído por uma nova república que recuperasse o funcionamento institucional imaginado nos primeiros anos da Revolução: regime representativo, garantias constitucionais, liberdade política e igualdade civil. A busca pela superação do período de "desinstitucionalização da política" (ROSANVALLON, 2000: 66) implica solucionar institucionalmente o desafio rousseauniano colocado pela república jacobina: como é possí- 
O Império da Opinião: Espaço Público, Opinião Pública e a Legitimidade...

vel uma república moderna na qual a liberdade do indivíduo-cidadão não seja dissolvida pela vontade amorfa de um coletivo universal indefinido - a soberania do povo - sempre presa do despotismo de um líder que pretende realizar a "vontade geral"?

Dito de outro modo, a equação apresentada pela Revolução ao liberalismo pode ser sintetizada da seguinte forma: como superar a "absolutização" da soberania do povo e as pretensões de um Estado instituidor da sociedade (ROSANVALLON, 2004: 11)? Essa questão, evidentemente redimensionada pelos problemas colocados pela história do desenvolvimento político da democracia, permanecerá como o centro da cultura do liberalismo político durante os dois séculos que sucederão à Revolução de 1789: a compreensão de que, a despeito do carácter expansivo da democracia liberal, a esfera da política nunca dará conta de maneira definitiva da diversidade crescente de demandas colocadas pela esfera do social. Assim, o conflito entre liberalismo e democracia permanecerá um problema aberto e constante na teoria política liberal.

Nesse sentido, o conceito de opinião exerce protagonismo no vocabulário do liberalismo político. No contexto francês da Revolução e da Restauração, a liberdade de imprensa e a ideia de opinião pública são mobilizadas para a construção de uma concepção de legitimidade que nega tanto o modelo monárquico quanto o modelo jacobino de soberania: não é mais o corpo soberano do rei que institui o cidadão e tampouco a soberania do povo que, agindo como um corpo unívoco, delega sua vontade ao representante excepcional. Ao contrário, a representação é uma atividade aberta exercida, por um lado, pelos mecanismos representativos da eleição e, por outro, pela existência de um "ator coletivo" por meio do qual é possível aferir os humores dos representados, a opinião pública. Pretendemos demonstrar como o liberalismo transforma a fonte de legitimidade do político: a sociedade, enquanto lócus da legitimidade, exerce sua função constituidora do poder legítimo não apenas através do procedimento periódico da eleição, mas especialmente por meio da constituição de um espaço público no qual narrativas pela melhor forma de organizar e conduzir o governo são articuladas e disputadas. Faremos isso a partir da investigação do conceito de opinião - e do vocabulário conceitual relacionado a ele - em alguns dos autores mais importantes do liberalismo político francês do final do século XVIII e início do XIX: Benjamin Constant, Germaine de Staël, François Guizot e Alexis de Tocqueville. Como veremos, esse ar- 
Paulo Cassimiro

gumento se caracteriza pelo tom fortemente anticontratualista e historicista: a opinião pública tem caráter eminentemente transitório; ela está submetida às transformações que o progresso material e moral da civilização impõe à política, sua possível expansão e os riscos que a instabilidade inerente à dimensão da opinião pode acarretar.

Seguindo certos parâmetros adotados especialmente por Reinhart Koselleck, buscaremos nos discursos dos atores envolvidos na luta política de determinado lugar e período a presença de conceitos e argumentos característicos, a fim de compreender como o contexto leva tais atores a lançar mão de determinados conceitos e atribuir-lhes significados novos. Assim, a mudança no significado do conceito de opinião pública obedeceria às quatro hipóteses que Koselleck oferece como distintivas da mudança conceitual operada com a modernidade: a temporalização, a democratização, a ideologização e a politização dos conceitos ${ }^{3}$. Ao mesmo tempo, a ênfase no exame dos problemas institucionais que conduzem à democracia e nos discursos que expressam essas transformações nos aproxima da história do político de Pierre Rosanvallon. Assim, do ponto de vista metodológico, é importante ressaltar que trabalhar com a história das ideias políticas é, ao mesmo tempo, "retrabalhar constantemente as antinomias constitutivas da experiência moderna" (ROSANVALLON, 2010: 52), ou seja, compreender as formulações teóricas e institucionais à luz da história do desenvolvimento político da democracia ${ }^{4}$.

Com isso, não pretendemos conferir um caráter teleológico ao trabalho, no sentido de afirmar que as ideias convergiriam todas para a culminação da experiência liberal-democrática no ocidente. Ao contrário, o que buscaremos é entender o pensamento político como espaço privilegiado no qual se expõem as "questões, perplexidades e as inovações" (Ibid: 52) das transformações históricas dos últimos três séculos, ao mesmo tempo em que nele encontramos as linguagens por meio das quais os atores políticos buscaram dar inteligibilidade à imaginação institucional e à ação política concreta. Essa ressalva metodológica pode ser compreendida como o principal instrumento para manter o trabalho da história das ideias a salvo do uso ideológico do "presentismo": localizar os discursos políticos em seu campo de conflito contextual pode nos ajudar a evitar que seja atribuída a eles uma "incompreensão conservadora", ao confrontá-los com etapas muito posteriores do desenvolvimento político da democracia. 
O Império da Opinião: Espaço Público, Opinião Pública e a Legitimidade...

\section{SECULARIZAÇÃO E TOLERÂNCIA.}

Para entendermos o problema da publicidade da opinião precisamos partir, mesmo que rapidamente, da questão da tolerância no debate intelectual europeu, especialmente durante o século XVIII, que acompanha o avanço do descolamento entre a religião e a sociedade. Naquele contexto, o debate sobre a tolerância surge como fundamento para compreender a criação de uma dimensão do discurso compreendida como a livre expressão das visões de mundo cuja legitimidade não precisa necessariamente derivar de uma autoridade estabelecida, política ou transcendente. Ao tratar o Estado moderno, entendido como solução para a paz civil encontrada no contexto dos conflitos religiosos dos séculos XVI e XVII, Bertrand Binoche nos lembra de que a república moderna pensada na chave do contrato social lockeano coloca no centro do problema a questão das relações entre o Estado e a igreja. Se, por um lado, o Estado fruto do contrato precisa garantir acima de tudo a segurança civil, entendida como reconhecimento inalienável da propriedade, por outro ele não pode garantir a ordem privilegiando uma religião em detrimento de outras (BINOCHE, 2012: 38). Assim, o contrato implica a criação de uma ordem social na qual a tolerância pertence, da mesma forma que a propriedade, à dimensão das garantias privadas que o poder constituído não pode alienar ao indivíduo/cidadão/proprietário. Não podendo estabelecer um fundamento moral comum para todos os homens no momento de fundação do contrato, a solução lockeana será, nas palavras de Pierre Manent, estabelecer que:

Nenhuma lei superior, nenhuma ideia de natureza ou de substância vem determinar, isto é, entravar essa criação individual do direito. Por outro lado, como esse direito individual se baseia originalmente nas necessidades da natureza animal, na fome que despoleta o trabalho, logo, na necessidade, não está exposto a qualquer objecção humana, a nenhuma objecção racional, é indiscutível. Esse direito é estabelecido, ou antes produzido, solitariamente, soberanamente, arbitrariamente pelo indivíduo e a sua criação é ao mesmo tempo estritamente necessária: a teoria que o desenvolve é, assim, comparável a uma demonstração matemática (MANENT, 1994: 176).

Assim, a tolerância é imposta ao direito criador da ordem como condição da existência de um indivíduo soberano. A busca por uma legitimidade que escape da dimensão do tradicional e do religioso leva o contratualismo lockeano a uma concepção de ordem política que 
Paulo Cassimiro

internaliza a religião, assim como o direito, à esfera do indivíduo - cuja existência se depreende do vínculo entre necessidades materiais e constituição da comunidade política -, expondo em termos políticos o processo de cisão entre religião e ordem social e política.

O modelo do direito natural lockeano vai ao encontro do que, segundo a teoria da secularização de Marcel Gauchet (1985), marca o segundo grande processo de autonomização que caracteriza a modernidade: enquanto o primeiro diz respeito à criação de uma ordem política - a do Estado moderno - que emancipa a soberania de seus fundamentos teológicos, o segundo descreve o surgimento de uma esfera distinta do Estado- a da sociedade civil - na qual impera o indivíduo/cidadão, cujos direitos condicionam a legitimidade do Estado. Como nos lembra Yves Charles Zarka, a elaboração filosófica inicial do conceito de tolerância envolve não só a limitação da esfera religiosa, mas igualmente o estabelecimento de seu fundamento: em primeiro lugar, cabe distinguir a ordem da autoridade política da ordem da autoridade eclesiástica - tarefa levada a cabo pela teoria de Locke - e, em seguida, fundar a tolerância sobre a liberdade de consciência - distinção cujo grande exemplo é a obra de Pierre Bayle (ZARKA, 2002: IX).

Mesmo aqueles que tentaram salvar a validade da experiência religiosa não conseguiram mais escapar ao paradoxo inevitável da verdade contra a pluralidade de visões de mundo. Binoche nos lembra que Benjamin Constant, após se retirar do debate político, dedicou os anos finais de sua vida à pesquisa que resultou na obra intitulada "Da Religião considerada em suas fontes, suas formas e seus desenvolvimentos" (De la religion considerée dans sa source, sas formes et ses developpements). Nela, Constant afirma que o sentimento religioso percorre toda a experiência histórica e civilizacional do homem e que permanece como fundo de expressões religiosas as mais diversas. Porém, é preciso distinguir o fundo e as formas: enquanto o primeiro é eterno e imutável, o segundo obedece a variações culturais as mais diversas e transitórias (BINOCHE, 2012: 72). Constant se dedica então a estudar as formas simbólicas da experiência religiosa, procurando entender como o fundo transcendental se expressa nas mais diversas instituições e culturas. O relativismo liberal de Constant colocado a serviço da história comparada das religiões nos revela mais uma vez a falência da crença transcendental como fonte da ordem política.

Assim, somos colocados diante de uma dupla dimensão da criação do indivíduo moderno como fonte e fundamento da legitimidade da or- 
O Império da Opinião: Espaço Público, Opinião Pública e a Legitimidade...

dem política. Como nos lembra Pierre Manent, "o homem é o ser que tem direitos; o homem é um ser de cultura". E completa, mais adiante, afirmando que "estas duas proposições nasceram da dissolução da noção de substância. Em compensação, condensam um movimento de pensamento no campo do qual a noção de substância ou a de natureza humana aparece como embaraçosa e estéril, inutilizável e desconcertante" (MANENT, 1994: 207). Mais do que um ser que tem direitos, o homem é a fonte da própria legitimidade do direito; a religião, por sua vez, é então relegada à esfera do direito privado dos indivíduos, e não mais reconhecida como constituidora dos valores comuns de uma ordem social legítima. Ao lado disso, o reconhecimento de que diversas experiências religiosas podem coexistir, na medida em que são todas elas fruto da capacidade humana em revestir de símbolos sua complexa relação com o sentimento religioso - ou seja, já que a religião não é mais que outra expressão da cultura - expõe definitivamente a emancipação da ação humana de suas fontes sagradas.

Chegamos aqui ao eixo central do argumento para o sentido geral do nosso trabalho: a descrença na existência de uma verdade alocada na dimensão da experiência religiosa permite a existência de um espaço concebido com a função de circulação da expressão de verdades parciais que disputam livremente a conquista das opiniões.

Com a opinião pública surge, com efeito, outra coisa que deve colocar fim à reconstrução de qualquer homogeneidade doutrinal, um golpe de gênio que deve oferecer à tolerância os meios institucionais de seu projeto. No lugar de se resignar em viver em conjunto por falta de coisa melhor, apesar dos desacordos cruciais sobre aquilo que mais deve importar, integra-se positivamente os desacordos em uma esfera na qual as oposições tornam-se forças motrizes. Não se relega mais aquilo que nos separa ao domínio das coisas indiferentes, mas organiza-se o confronto regulado pela responsabilidade do corpo social inteiro. Não se vive mais juntos apesar das diferenças, mas se toma a própria diferença como apoio para a vida em conjunto (BINOCHE, 2012: 73).

Assim, a constituição de uma dimensão pública e livre pressupõe o confronto entre opiniões, mesmo considerando a possibilidade de sua superação e correção. Podemos afirmar, seguindo o raciocínio de Koselleck, que a sociedade burguesa expande a dialética do iluminismo, que se movimentava por meio do processo de crítica e desmascaramento contínuos (KOSELLECK, 1999: 140), “democratizando" a República das Letras ao transformar o espaço público na arena de disputa de 
discursos sobre o próprio sentido do processo de esclarecimento do espírito e da sociedade. Para Koselleck, "mesmo tendo alcançado o poder, e precisamente nesse estágio, a opinião pública oculta o soberano. A tarefa mais importante do novo legislador, do qual todo o resto depende, consiste em substituir a autoridade pelo poder da opinião pública" (Ibd.: 144).

\section{A OPINIÃO PÚBLICA E O PROJETO ILUMINISTA: DO ESCLARECIMENTO À EMANCIPAÇÃO DA SOCIEDADE.}

Em seu ensaio "Sobre a influência das paixões sobre a felicidade dos indivíduos e das nações" (De l'influence des passions sur le bonheur des individus et des nations), Madame de Staël chama atenção para o fato de que em momentos de revolução apenas a ambição ou a convicção podem ser meios de se obter o poder. "A opinião que distribui a glória não existe mais; o povo comanda ao invés de julgar. (...) O poder imparcial, que chamamos o público, não existe em nenhuma parte" (STAËL, 1858, T.II: 37-38). Staël concebe o espaço público no qual reina a opinião como uma dimensão pós-revolucionária: a opinião pública é um instrumento do poder constituído, não pode funcionar em circunstâncias onde o exercício regular das instituições esteja suspenso pela eclosão de eventos excepcionais.

Ao refletir sobre a possibilidade de um governo institucionalmente estável, que superasse o período de instabilidade política que havia arrastado a Revolução a partir da ascensão dos jacobinos ao poder em 1793, Staël insistirá em vários momentos que a República adequada à liberdade moderna deve estar sustentada na opinião pública. Para ela, uma das causas da decadência da república dos romanos foi a inexistência de uma dimensão da sociedade capaz de avaliar de maneira "justa a apreciação de virtudes e de talentos, para lhes honrar por sua estima" (STAËL, 1858, T.II: 221). "Estima" (estime), "glória" (gloire), "eloquência" (éloquence) e "opinião" (opinion) são algumas das palavras que se relacionam na obra de Staël com uma concepção do público eivada da ideia de um progresso das luzes (lumières) em direção ao aperfeiçoamento e à felicidade da espécie humana (Ibid: 417). O conceito de opinião pública em Staël se encontra no limiar da concepção da opinião pública do século XVIII como algo que distribui a estima e responde pelo sucesso público dos homens célebres, e sua concepção no sentido político propriamente liberal, ou seja, como instrumento do exercício constante do poder do público na esfera do político. 
O Império da Opinião: Espaço Público, Opinião Pública e a Legitimidade...

Porém, em sua obra não publicada, "Sobre as circunstâncias atuais que podem terminar a Revolução na França" (Des circonstances actuelles qui peuvent terminer la Revolution em France) - que, não obstante, circulou pelos salões liberais durante os anos finais da Revolução e influenciou especialmente Benjamin Constant que, segundo Biancamaria Fontana (1991: 35) comentou a obra em um manuscrito entregue à autora -, Staël tocará a questão em termos mais próximos do discurso político liberal. Para ela, a liberdade de fato que o governo representativo proporciona advém em grande parte do fato de ser ele presidido pela opinião pública (Id., 1902: 162). Ela distingue essa opinião pública da opinião que vigorava na ágora de Atenas, condição da democracia pura. A distinção entre a opinião pública moderna e a praça pública dos antigos serve também para diferenciar o regime representativo e a ambição da democracia pura com vestes gregas dos jacobinos, que é interpretada por ela como uma corrupção da liberdade dos antigos. Existe, portanto, uma república moderna onde a opinião pública impera.

Em um país livre - estando quase sempre a opinião dividida entre dois partidos - o que chamamos de estima pública tem sempre menos força e menos severidade; a igualdade política destruiu o tipo de subordinação imaginária que mantém cada homem contido em sua esfera; cada pensamento e cada ação são julgados sempre de duas formas diferentes, independentemente da gradação dos poderes (Ibid: 212).

A opinião pública e a estima pública se desassociam na medida em que as condições de igualdade avançam. Dito de outro modo, a opinião pública pressupõe a existência de certo grau de igualdade política, produzindo um espaço no qual o conflito dos discursos se realiza dentro de uma expectativa de conflito regulado, em uma "economia retórica" da opinião, baseada no cálculo dos efeitos que o discurso causará no espaço público em termos de mobilização política e de conquista de corações e mentes. Nesse sentido, o conceito de opinião pública passa por um processo de politização - segundo Koselleck (2011: 15), um dos quatro processos fundamentais que marcariam estruturalmente a transformação dos conceitos no período entre fins do século XVIII e início do XIX ${ }^{5}$.

A tese de Montesquieu segundo a qual o princípio da República é a virtude - entendida não como virtude cristã, mas como virtude política, ou seja, amor pela liberdade e pela igualdade republicanas - é insuficiente para a liberdade na República do indivíduo moderno. Para Staël, "se Montesquieu viesse a nossos dias, talvez ele pensasse que o 
princípio da República francesa fosse a filosofia" (STAËL, 1902: 82) e completa, mais adiante, afirmando que "todo ato legislativo deve derivar do pensamento do filósofo adotado pela opinião pública" (Ibid.: 191). A filosofia como princípio da opinião pública nos coloca diante do problema da relação entre os filósofos e a República. Staël e Benjamin Constant ecoam a opinião corrente de que o processo revolucionário havia sido iniciado pela ação transformadora dos filósofos nos espíritos do século XVIII. "Os filósofos fazem avançar o espírito público mais rápido e mais adiante do que uma educação nacional" (Ibd.: LXIII).

Nesse ponto, contudo, vemos surgir uma diferença entre a obra de Staël e a de seu amigo Benjamin Constant, essencial para entendermos a teoria da opinião pública na obra deste último. Apesar de reconhecer o protagonismo do filósofo para os eventos que resultam na Revolução, Constant se tornará crítico do papel providencial do homem de gênio para a emancipação e o esclarecimento do povo. Nos "Comentários sobre a obra de Fillangeri" (Commentaires sur l'ouvrage de Fillangeri) encontramos diversas passagens em que Constant contrasta o papel modernizador do filósofo do século XVIII com a existência de uma sociedade fundada no princípio da liberdade, criticando a tentativa dos iluministas de produzir reformas por meio da conquista dos espíritos e da autoridade. Constant afirma que os projetos iluministas de mudança da ordem social confiaram na possibilidade de transformar a autoridade do poder absoluto num agente da liberdade e da igualdade por meio da ilustração da aristocracia e dos governantes, "mas novatos na ciência, eles pensaram que um uso diferente desta mesma autoridade faria tanto bem quanto seu uso vicioso causou o mal" (CONSTANT, 1882, I: 13). Porém, era a própria natureza centralizadora do poder absoluto que impedia o progresso das luzes. Este não reside numa casta ou na possibilidade do absolutismo ilustrado, mas na existência de uma massa de homens dotados de direitos fundamentais e admitidos na participação dos assuntos públicos.

O que caracteriza os amigos do poder é sua confiança em certas classes e em certos homens. São atribuídos a eles certos direitos inatos e luzes privilegiadas. Em consequência, eles se submetem pouco às instituições, e eles não as invocam senão como defesa, quando temem que a autoridade concentrada na mão de alguns não lhes seja favorável. Aqueles que, ao contrário, pensam que a opinião deve ser obedecida, que os governos devem não ser mais que intérpretes, e que sua missão é progre- 
O Império da Opinião: Espaço Público, Opinião Pública e a Legitimidade...

dir, acreditam que é preciso que se constitua uma nova instituição para garantir o lugar a cada passo do aperfeiçoamento conquistado pela humanidade. Não se quer, na verdade, que essas instituições sejam imutáveis; o que se quer é que a opinião, cuja força progressiva constitui novas instituições, possa interferir e aperfeiçoá-las ainda mais. Mas, na medida em que não se reconhece no poder a ciência e a superioridade das luzes, não se confia nada nele, e se recorre às instituições para registrar e proteger os progressos feitos quase sempre a despeito dos esforços do poder para retardá-los. (Id., 1822, T.II: 288-289).

Nesse sentido, o papel do filósofo não é formular um projeto de esclarecimento que se realiza por meio do Estado, mas exercer suas funções em um espaço público fundado na existência da liberdade política. Essa diferença marca uma cisão fundamental entre o projeto iluminista de despotismo ilustrado e a concepção de ordem social e política dos liberais pós-revolucionários.

A sociedade civil enquanto esfera do domínio do indivíduo-cidadão é a dimensão do político própria ao exercício da opinião pública, na medida em que é nela que a prática transitória das opiniões se desenvolve. O conceito de "convenções legais" (conventions légales) que Constant desenvolve no seu tratado sobre a perfectibilidade humana expressa de forma exemplar essa concepção. Ele insiste que as convenções no mundo anterior à Revolução estavam fundadas em princípios que mascaravam a verdadeira liberdade: os preconceitos, os erros e as venerações supersticiosas. O fim da Revolução marca o começo de uma época nova, aquela que Constant chama de "convenções legais", um tipo de razão comum, mais razoável que a força e menos abstrata que a razão.

O produto médio de todas as razões individuais, mais imperfeita que a razão de alguns, mais perfeita que a de muitos outros. (...) Em se tratando de convenções legais, é preciso compreender que elas não são coisas naturais ou imutáveis, mas coisas factuais, suscetíveis de mudança, criadas para substituir verdades ainda desconhecidas, para suprir necessidades momentâneas e, por consequência, para serem emendadas, aperfeiçoadas, e mesmo limitadas, na medida em que a verdade se desdobra ou que as necessidades se modifiquem (CONSTANT, 1997: 718-719).

Ora, podemos inferir do argumento de Constant que as convenções legais são os desdobramentos da opinião pública no exercício do poder e

DADOS - Revista de Ciências Sociais, Rio de Janeiro, vol. 61, n 3, 2018 
da legislação. Elas fazem parte de uma razão média, ao abrigo do arbítrio e da influência de um legislador rousseauniano - aquele dotado de uma missão providencial com atributos superiores à média dos homens. O desvelamento progressivo da verdade que está em processo por meio do aperfeiçoamento do homem é traduzido em termos práticos por meio de uma razão transitória que reconhece seu caráter artificial e limitado, mas ainda assim público, onde o homem "não precisa consultar nada além de si mesmo" (Ibid: 719). Dessa forma, Constant insere o problema da opinião pública no contínuo de sua teoria do conhecimento, que é também uma teoria da história e da ação humana ${ }^{6}$. A gênese da modernidade política implica, portanto, não só no reconhecimento da polissemia de opiniões, mas na transitoriedade da ação e da decisão política, na medida em que ela não é mais que o desdobramento contingente de uma verdade paulatinamente revelada no curso do aperfeiçoamento humano.

A verdadeira convenção legal, aquela fundada na legitimidade do indivíduo-cidadão, realiza-se em um mundo onde "não se reconhece mais um poder oculto que tenha o direito de comandar a razão, [no qual] o homem não quer consultar senão a ela, e não se presta a convenções que não resultem de uma transação com a razão e seus semelhantes" (Id, 1997: 719). O conceito de convenções legais ressalta o caráter processual do político em Constant: a legitimidade da ordem é reiterada e reforçada no contínuo do funcionamento da representação e, fundamentalmente, na relação entre representação e opinião pública. $\mathrm{O}$ aperfeiçoamento da república se dá no espaço de conflito estabelecido por uma sociedade organizada pela liberdade pública e pela igualdade civil, estabelecendo o que Constant chama de perfeição relativa.

A questão das convenções legais e seu desdobramento transitório é um dos desenvolvimentos da marcha da espécie humana, objetificação no mundo da potência individual da perfectibilidade (Ibid: 719). A verdade, assim como a perfectibilidade, não é um fenômeno de ordem convencional, mas pertence à dimensão subjetiva do indivíduo moderno. A propriedade característica do pensamento é partir da incerteza e da irresolução para alcançar a verdade. O que caracteriza a transitoriedade da lei é o seu caráter sempre aberto à transformação. A condição para a busca da verdade política no espaço público - e, por conseguinte, para o processo de aperfeiçoamento da própria ordem social que tem início quando se funda uma constituição baseada no princípio da liberdade política - é a admissão da possibilidade do erro: "o direito de 
O Império da Opinião: Espaço Público, Opinião Pública e a Legitimidade...

que tenho mais inveja é o direito de me enganar. Sem esse direito não existe independência de opinião nem possibilidade de liberdade individual" (Ibid: 76). A verdade como instrumento da conquista do poder, sob a justificativa da "realização das luzes", é duramente atacada por Constant como um tipo de "despotismo esclarecido".

Luc Ferry e Alain Renaut nos lembram de que Fichte escreve, durante a Revolução Francesa, um tratado no qual argumenta que a ideia do contrato social está em flagrante contradição com a concepção da história como um horizonte aberto de ação humana e de transformação. Para justificar a possibilidade de mudança da constituição política, Fichte afirma que "a cláusula que declara o contrato social imutável está em contradição com o espírito da humanidade, [...] com o privilégio de se aperfeiçoar infinitamente" (FICHTE Apud FERRY; RENAULT, 2007: 388). Se o governo é fruto de um contrato, não estamos autorizados a transformá-lo a menos que esse contrato seja rompido. O contrato social pensa a história como um rompimento ente o estado de natureza pré-social e a constituição da comunidade política, no qual a desordem e a ordem são estados alcançados a partir da constituição ou da corrupção de um contrato fundador. Porém, quando a filosofia jusnaturalista é progressivamente substituída por um modo historicista de se pensar a constituição da ordem política, é a própria natureza do tempo histórico que transforma a compreensão da legitimidade do político. Enquanto a primeira tende ao imobilismo, a segunda tende a justificar-se por conceitos que expressam a possibilidade de uma abertura temporal para a mudança. Em verdade, como dirá Giuseppe Duso (2015), o argumento de Fichte contra o contratualismo remete à crítica da representação como apenas um procedimento de autorização do poder legítimo.

Essa transformação implica uma mudança na própria concepção do direito. Se o contrato deve ter como princípio a sobrevivência de direitos naturais pré-sociais, a negação do contrato não implica em um positivismo absoluto, ou seja, na validade universal de qualquer ordem social e política constituída. "Nenhum direito natural, ou seja, nenhuma relação jurídica entre os homens é possível senão no seio de um ente comum e sob leis positivas. [...] o Estado mesmo torna-se o estado de natureza do homem, e suas leis não são nada além do direito natural realizado" (FICHTE Apud FERRY; RENAULT, 2007: 289). A relação entre poder constituinte e poder constituído, entre a dimensão pré-política na qual reside a legitimidade e a constituição do direito, é inserida no

DADOS - Revista de Ciências Sociais, Rio de Janeiro, vol. 61, n 3, 2018 
contínuo do desenvolvimento e da expansão da legislação e das funções do Estado. O direito natural permanece vivo não a partir da dinâmica jusnaturalista, mas pensado como princípio de controle da lei e dos agentes responsáveis por sua formulação, e é exercido pela observação da constituição e dos direitos individuais. Em outras palavras, a linguagem do direito natural dá lugar à linguagem das garantias e dos direitos fundamentais.

Nesse sentido, o liberalismo de Constant pensa o processo de transformação e expansão do direito não a partir de uma decisão do corpo soberano, mas da criação de uma ordem cuja legitimidade advém da sociedade civil e cujo poder se exerce através de uma dimensão real - a representação - e outra virtual - a opinião pública. A confiança não está depositada no mérito do legislador e na sua capacidade de encarnar com mais ou menos precisão a vontade virtuosa do corpo soberano, mas na capacidade da ordem política para produzir espaços de manifestação e autodeterminação coletiva que são, em verdade, etapas transitórias em direção ao aperfeiçoamento contínuo da comunidade política. A dinâmica institucional do mundo pós-revolucionário não se traduz, em verdade, no esforço de reconhecer e representar uma vontade soberana, mas de interpretar no espaço público a "opinião média" da sociedade. A opinião é interpretada como a primeira das garantias essenciais para a limitação do poder, mais até do que a separação dos poderes e o regime representativo: no seio de uma sociedade em que a opinião não está disposta à liberdade, o despotismo frutifica com facilidade (Constant, 1887: 315).

Ao reconhecer o caráter plural da opinião, Constant admite também que o espaço público é composto por uma variedade de interesses - entendido como expressões de vontades particulares. Assim, ele rompe definitivamente com o caráter absolutamente objetivo e unitário do conceito de soberania da nação sieyèsiano, no qual a legitimidade delegada deveria partir de uma concepção totalizante de bem público, sem reconhecer o interesse privado como fonte legítima da representação. Porém, mesmo reconhecendo que o interesse motiva a opinião, Constant - assim como Staël - ataca duramente o utilitarismo. Mauro Barberis, em sua obra sobre Constant, dedica-se a entender a crítica do suíço a Bentham. Ao romper com o direito natural, Bentham descarta toda possibilidade de submeter a regra ao julgamento dos governados, tomando-a, portanto, como uma decisão pura do legislador; assim, a lei confere o direito, e não o contrário (Barberis, 1988: 284). Constant 
O Império da Opinião: Espaço Público, Opinião Pública e a Legitimidade...

ataca duramente a filosofia de Bentham, afirmando a impossibilidade de uma ordem que não se componha de um elo entre a norma e a sociedade: a própria ideia de delito pressupõe um acordo prévio entre o legislador e o governado, sem o qual a convenção sobre o que é um delito seria impossível (Ibid: 285). Da mesma forma, Staël afirma que "o direito é um princípio, a utilidade não é senão um resultado". E completa, mais adiante, ao afirmar que "a utilidade política não é de forma alguma uma ideia precisa, ela se alimenta de uma falsa combinação para convencer os homens poderosos de que uma injustiça tem vantagens políticas e para que eles façam de um dever a violação dos deveres do homem" (Staël, 1906: 230).

Constant afirma que o homem frequentemente sacrifica a utilidade imediata por uma sensação futura. Sendo assim, "devemos concluir que existe na natureza humana uma disposição que lhe dá perpetuamente a força de imolar o presente em nome do futuro e, por consequência, a sensação em nome da ideia" (Constant, 1997: 705). A ideia, portanto, é a verdadeira fonte de ação política; e, dentre todas, a ideia de justiça é aquela que movimenta o homem para a necessidade de criar leis que regulem a ordem social. A defesa de um princípio de justiça que anteceda a lei é o próprio fundamento da ontologia liberal de autores como Constant e Staël, cujo resultado político é a existência de direitos fundamentais sobre os quais o regime constitucional deve velar. Assim, o interesse - ou seja, o cálculo dos benefícios privados que motivariam a ação pública na comunidade política - não é um princípio de ordem, mas um meio, variável e relativo, que movimenta os homens para a ação política no espaço público. Dito de outro modo, para o liberalismo de autores como Staël e Constant o interesse privado é o movente da ação política, mas não é o fundamento da ordem social, como no utilitarismo de Bentham.

Ora, negado o utilitarismo, permanece sem solução a questão da validade do fato fundamental que antecede o direito, ou seja, o problema do fundamento da ordem política liberal: se não é o direito natural jusnaturalista, o que faz do homem a fonte do direito? O que faz do homem o protagonista de um conjunto de direitos que limitam a soberania, e não o contrário, como na teoria clássica da soberania do rei, onde o poder real é que cria o cidadão? Pierre Manent nos lembra que é na tentativa de solucionar esse impasse que Constant eleva a história, e não a natureza, como o eixo de sua explicação (Manent, 1990 184): a fundação de uma ordem constitucional dá origem a um horizonte de 
Paulo Cassimiro

expectativas orientado pela ideia de progresso; e é graças à crença na perfectibilidade humana que a liberdade, tornada direito, promove mais liberdade ${ }^{7}$. É assim que teoria da história e teoria constitucional se associam no pensamento de Constant para formular uma ordem na qual as disputas por um futuro aberto são o centro de um espaço, fonte de legitimidade política, no qual a opinião pública é protagonista. Oliberalismo do sujeito, para lembrarmos a expressão de Lucien Jaume (1997), não é de forma alguma uma concepção de um sujeito sem regras, puro objeto do direito positivo e movido pelo cálculo utilitário, mas antes um sujeito cuja própria natureza perfectível realiza-se na existência de uma esfera que determina a legitimidade da ordem política: a sociedade civil.

\section{OPINIÃO PÚBLICA E RAZÃO PÚBLICA.}

Insistimos na seção anterior em classificar o pensamento de Staël e Constant de liberalismo do sujeito, utilizando a categoria de Lucien Jaume em seu estudo sobre a história do liberalismo. Porém, o liberalismo francês apresenta outra faceta, cuja influência política se materializou com grande importância durante a Monarquia de Julho (1830-1848), na qual o liberalismo é pensado menos como a teoria da preservação dos direitos individuais e mais como uma forma de reunir os interesses comuns da sociedade (JAUME, 1997: 121). Essa face do liberalismo político francês é representada de forma mais complexa e exemplar pela obra de François Guizot. Nas palavras de Pierre Rosanvallon, "Guizot recupera, assim, a interpretação organicista do político no interior da percepção de uma ruptura radical na natureza da sociedade"; e completa, afirmando que "ele não pensa o social em sua globalidade e generalidade (homens / povo), mas em sua realidade prática de classe (a burguesia como agente social caracterizado)" (Rosanvallon, 1985: 49). Para Guizot, a liberdade é pensada como uma determinada cooperação que resulta em uma força social capaz de garantir certa quantidade de liberdade para um determinado grupo. Nesse sentido, o garantismo liberal dá lugar, em Guizot, a um tipo de cálculo da liberdade, sendo a soberania a origem desse cálculo, recolhendo na sociedade os elementos que a compõem. O Estado legítimo ainda é fruto de um poder social, cuja materialidade também é pensada na chave dos mesmos conceitos que o liberalismo do sujeito: o governo representativo e a opinião pública. Contudo, o conceito de opinião pública aparece quase sempre subsumido a outro cuja função é central 
O Império da Opinião: Espaço Público, Opinião Pública e a Legitimidade...

para compreendermos a teoria da legitimidade do político em seu pensamento: o conceito de razão pública (raison publique).

Para definir o problema, Guizot parte justamente da complexa relação entre verdade e pluralidade de opiniões para definir o caráter do corpo social. Ele reconhece que em qualquer sociedade um conjunto de "ideias justas" (idées justes) e "vontades legítimas" (volontés legitimes) orientam as relações sociais. Na medida em que estas ideias e vontades se encontram dispersas na sociedade, é preciso reconhecê-las e reuni-las para a constituição de uma ordem política. A imposição da obediência, portanto, parte da necessidade de encontrar um instrumento que transforme o espaço de conflitos e de interesses privados dispersos em um poder social legítimo. Porém, na medida em que partimos de um estado em que não existe ainda um poder legítimo constituído, tal instrumento deve encontrar sua legitimidade em si mesmo. Este poder, aponta Guizot, é o "poder da razão, da justiça e da verdade" (Guizot, 1880, T.II: 150) que, sendo legítimos em si mesmos, podem impor obediência. O problema do político é, portanto, identificar na sociedade a diversidade de razões individuais e realizá-la na constituição do poder.

O problema é, evidentemente, recolher por todas as partes os fragmentos esparsos e incompletos desse poder, concentrá-los e constituí-los em governo. Em outros termos, se trata de descobrir todos os elementos do poder legítimo disseminados na sociedade e organizá-los em um poder de fato, quer dizer, de realizar a razão pública, a moral pública, e de chamá-las ao governo. O que chamamos a representação não é outra coisa que o meio de chegar a esse resultado" (Ibid: 150).

A razão pública é o próprio instrumento que identifica e reúne os elementos legítimos que compõem a barafunda do social. Combatendo veementemente o argumento rousseauniano, Guizot nega que a representação seja fruto de um "cálculo das vontades"; a razão não foi repartida igualmente entre os homens e, por conseguinte, a vontade de cada um não é capaz de construir consensos legítimos. "No sistema de representação das vontades nada pode justificar tal limitação [da participação no poder], pois a vontade existe plenamente em todos os homens, e confere a todos um direito legal; mas a limitação resulta necessariamente do princípio que atribui o poder à razão, não à vontade" (Id., 1880, T.II: 151).

Contudo, o princípio de verdade derivado da razão está ainda condicionado por alguns elementos que permitem ao pensamento de Guizot

DADOS - Revista de Ciências Sociais, Rio de Janeiro, vol. 61, n 3, 2018 
Paulo Cassimiro

se manter no contexto da teoria liberal. A existência do indivíduo-cidadão ainda é o ponto de partida indiscutível de seu pensamento: "nenhuma razão tem, por si mesma e antes de tudo, o direito de dizer que ela é a razão pública. Se ela assim o pretende, é preciso que prove, quer dizer, que ela se faça aceitar como tal pelas outras razões individuais que são capazes de julgá-la" (Ibid: 150). Guizot ressalta, assim, o caráter público da razão: ela não é apanágio de um legislador iluminado, mas resultado da compreensão e da deliberação de um espaço público organizado, mesmo que condicionado pelo princípio da capacidade. Dessa forma, o conceito de razão pública retorna aqui ao problema da opinião: o primado do político organizado a partir de um espaço público existente no seio de uma sociedade liberal permanece vivo no pensamento de Guizot. Porém, na medida em que o centro de seu liberalismo desloca-se do indivíduo para certa apropriação geral do social, a ideia de opinião dá lugar à de razão, entendida como o instrumento que reconhece o poder legítimo na dimensão amorfa e conflituosa do social.

Bem entendido: todas as instituições, todas as condições do sistema representativo, derivam deste princípio e retornam a ele. A eleição, a publicidade, a responsabilidade são algumas das provas impostas às razões individuais que, ao buscar ou ao exercer o poder, se pretendem intérpretes da razão pública; são todos meios de iluminar os elementos do poder legítimo e de prevenir a usurpação (Ibid: 150).

Ora, a constituição de um poder legítimo não está, então, apenas condicionada pela necessidade da adequação entre ordem e verdade. A razão pública - instrumento desta adequação - só pode emergir se o espaço público obedecer a alguns princípios que não são outros senão os da liberdade política; esta, para Guizot, também é fruto de um processo histórico que se realiza na modernidade. Ele nos apresenta em sua História da Civilização na Europa (Histoire de la Civilisation en Europe) a evolução da civilização europeia como uma transição entre o elemento germânico, bárbaro e governado pelo predomínio da dimensão privada sobre a pública, e o cristão, caracterizado por um maior equilíbrio entre a liberdade individual e a tentativa de organização de uma autoridade externa legítima. A concepção historicista de Guizot que explica o desenvolvimento da liberdade moderna estabelece, então, duas garantias essenciais que o sistema político moderno deve sustentar para ser legítimo: "uma se encontra na publicidade da luta (...). A segunda garantia consiste na fixação de condições de capacidade impostas 
O Império da Opinião: Espaço Público, Opinião Pública e a Legitimidade...

como princípio a qualquer um que aspire exercer alguma porção do poder (Ibid: 151).

Assim, o sistema de participação e representação evocado por ele está condicionado à necessidade de estabelecer condições de capacidade estruturais. A chamada "ordem capacitária", uma norma que ambiciona estabelecer os "limites naturais" da política definindo, através da lei eleitoral, certas capacidades que devem ser condição do direito à participação, é a solução prática apresentada por Guizot para aplicar a razão pública ao sistema político. "Qualquer um que pretenda exercer o poder é obrigado a provar que ele o exerce ou exercerá não segundo sua vontade, mas segundo a razão" (Ibid: 153). A mecânica da ordem capacitária não implica de forma alguma em censura ou em limitação das liberdades; a despeito de definir a finalidade da liberdade, Guizot não nega a existência de um espaço público no qual o conflito das opiniões se desenvolva livremente. "A liberdade de imprensa [...] corresponde a uma necessidade social. Ela não é apenas o exercício de uma faculdade natural, prolongamento da liberdade individual: ela é um dos elementos de um 'novo estado das sociedades'" (Rosanvallon, 1985: 66). Porém, o reconhecimento dessa liberdade não é nunca pensado na chave do exercício de um direito individual, mas sempre em relação à capacidade dos atores políticos de se apropriar das forças do social na criação de consensos. Assim, Guizot irá estabelecer uma diferença substantiva entre a razão pública e a opinião que resulta de "preconceitos" sociais.

Guizot nega que exista uma diferença substantiva entre opiniões públicas e interesses privados. Na medida em que as opiniões se apresentam, cabe ao político saber governa-las e conduzi-las sem distinguir se são originadas em convicção ou em um interesse. "Os princípios engendram os fatos, os fatos se escondem por trás dos princípios" (Guizot, 1985: 138). Sendo assim, a origem da opinião não importa; é preciso reconhecer que o social é composto de uma diversidade incontável de "expressões comuns" e "frases vulgares" que, no entanto, nos permitem compreender o "instinto público" (Ibid: 138-139). Guizot designa como "instinto público" a opinião vulgar das massas, tudo aquilo que, sem se sustentar pelo exame criterioso da razão, serve como meio de expressar um desidério político; são opiniões herdadas do passado ou da apreensão impressionista de juízos filosóficos que se convertem em convicções políticas. O problema, então, é saber como o poder deve lidar com a opinião: tomando-a como meio, e não como ad-

DADOS - Revista de Ciências Sociais, Rio de Janeiro, vol. 61, n 3, 2018 
versário, do governo. Dito de outro modo, governar a partir da razão pública significa também governar com os instintos públicos que caracterizam o residual, o ambiente criado pela liberdade pública no qual o governo, constituído pela razão pública, irá encontrar o objeto a ser governado. Para Guizot, "longe de ser permitido à política tratar das opiniões com uma ligeireza arrogante, ela precisa tomá-las com grande consideração; poderosos meios de governo são considerados como rudes obstáculos" e completa, mais adiante, "e a falta mais grosseira que o poder pode cometer hoje em dia é negligenciar de se servir delas ao invés de temê-las" (Ibid: 141). A sociedade moderna implica, portanto, em uma nova relação entre governo e opinião.

Poderíamos a princípio dizer que, ao encarar a diversidade de opiniões políticas não como um espaço de busca de consensos, mas como um instrumento a ser capturado pelo governo, a teoria de Guizot parte de uma relação fundamentalmente cínica com o liberalismo. A razão de Estado se mascara na busca por uma legitimidade que não pode prescindir da sustentação da opinião em uma ordem política organizada pelo princípio dos direitos individuais e do sistema representativo. É bem verdade que a interpretação majoritária da obra de Guizot aponta para a precedência do Estado sobre a sociedade em seu modelo teórico, o que poderia aproximá-lo mais de um tipo de conservadorismo com concessões às liberdades modernas. Lucien Jaume, por exemplo, estabelece uma oposição radical entre duas correntes do liberalismo político francês oitocentista: a primeira, ligada historicamente a Madame de Staël e Benjamin Constant, constituiria um liberalismo do sujeito, da consciência ou do indivíduo, e privilegiaria as garantias do indivíduo contra o Estado; a segunda, ligada a Guizot e aos doutrinários, ${ }^{8}$ constituiria um liberalismo elitista, e privilegiaria, ao contrário, "os direitos do poder público, a quem caberia estabelecer as regras de expressão dos direitos individuais e, finalmente, sua extensão" (Jaume, 1997, p. 19). Tendo a corrente representada por Guizot exercido uma influência política maior na história francesa, justificar-se-ia uma das teses centrais do livro de Jaume: "O liberalismo francês adotou, de modo bastante majoritário, a segunda via, a de um liberalismo pelo Estado, e não contra ou fora do Estado" (Ibid: p. 11).

Porém, é preciso considerar os desafios diante dos quais o pensamento dos doutrinários se organiza como um tipo muito específico de liberalismo. A sociedade que emerge da queda de Bonaparte tenta se equilibrar entre a reconstrução de uma autoridade legítima e a convivência 
O Império da Opinião: Espaço Público, Opinião Pública e a Legitimidade...

com uma nova linguagem política conquistada com a Revolução. Dito de outro modo, a linguagem da liberdade e da igualdade que surge da Revolução abre uma nova perspectiva de expectativas para a ação política com a qual o poder constituído tem que lidar, na medida em que ele se constitui justamente sob a condição da manutenção de um espaço público no qual essa linguagem se reproduza. Ora, se é verdade que o liberalismo de Guizot pensa o Estado como a esfera de realização da modernidade política, essa concepção não se confunde em nada com o Estado compreendido como um corpo soberano do qual emana a legitimidade do poder político, ou seja, como um corpo político autôno$\mathrm{mo}^{9}$. O Estado é pensado como objeto da representação ao mesmo tempo em que é a única forma de realização desta: a representação precisa encontrar na sociedade os elementos da razão, ela precisa extrair a razão pública da massa indeterminada da sociedade. Nesse sentido, representação não é pensada como delegação de vontades individuais, mas como forma de constituição de elites. "Tudo que podem fazer é conferir aos seus representantes a missão de examinar e decidir o melhor curso da ação de acordo com sua própria razão e julgamento" (Craiutu, 2003: 219) ${ }^{10}$. O desafio colocado pelo pensamento de Guizoté o de como pensar essa nova e inevitável dimensão do político não contra o poder - como o liberalismo do sujeito o faz - mas a partir dele, ou seja, a partir da constituição de uma nova autoridade legitimada por essa nova concepção do público. A opinião pública é o local por excelência de permanência da herança revolucionária: lidar com ela e convertê-la em um efetivo meio de governo, em um "mercado político" no qual o Estado coletará a razão pública, é o verdadeiro objetivo do liberalismo doutrinário de Guizot.

\section{O ESPAÇO PÚBLICO E A POSSIBILIDADE DA REPÚBLICA NO ESTADO SOCIAL DEMOCRÁTICO.}

O conceito de razão pública expõe essa intrincada relação entre o político e o social que surge do problema da opinião: o nivelamento dos costumes conduz ao "rebaixamento" das ideias ao nível do discurso popular; contudo, é a existência de um espaço garantido pelo princípio da liberdade no qual essas opiniões "rebaixadas" circulam que permite à sociedade democrática manter o princípio republicano de vigilância e controle do poder legítimo. Como Tocqueville - aluno de Guizot durante a juventude, e que mais tarde reivindicará a herança do método historiográfico do professor - lembrará mais tarde, é o princípio da mobilidade que acompanha o desenvolvimento da democracia que 
permite à opinião se fixar em instituições e costumes por um longo prazo. A natureza da opinião na modernidade, portanto, obedece a um princípio inverso ao da Revolução: ela não opera por rupturas abruptas, mas por uma transformação contínua que acompanha o próprio ritmo das transformações na sociedade (Tocqueville, 1986b: 359). Ao descobrir a utilidade comum da liberdade e consolidá-la por meio da criação de espaços nos quais ela vigore, a democracia substitui a necessidade das revoluções por um processo contínuo de atualização da razão pública por meio da opinião.

Contudo, a questão da estabilidade das opiniões na democracia pode constituir um problema. Para Tocqueville, as opiniões se solidificam na medida em que os indivíduos não estão dispostos a arcar com o custo social de seu questionamento: uma vez que a posição social na democracia não se dá por contraste, mas por reconhecimento mútuo entre iguais, questionar publicamente uma opinião estabelecida pode resultar em um custo social considerável. "Todas as vezes em que as condições são iguais, a opinião geral pesa de uma forma imensa sobre o espírito de cada indivíduo; ela o envolve, o dirige e o oprime: isso concerne à constituição mesma da sociedade, muito mais do quae à suas leis políticas" (Ibid:358). A opinião, portanto, ecoa o reiterado tropo do potencial despótico da democracia: à medida que as condições se nivelam, os indivíduos se tornam mais fracos diante das forças que representam a comunidade. A opinião estabelecida na democracia tem força de lei; a discordância pode ser vista como uma insurreição contra o próprio caráter democrático da sociedade. A opinião, portanto, não é apenas um instrumento de resistência e limitação do poder; ela pode resultar também em um esvaziamento do espaço público.

Se a uniformização dos critérios de distinção social pode levar ao nivelamento autoritário da opinião, a democratização, como tendência histórica, pode caminhar para a dissolução do complexo sistema de equilíbrio institucional na qual se funda a concepção liberal de constituição. Há, portanto, uma oposição fundamental que subjaz ao argumento, um conflito entre liberalismo e democracia inerente à dinâmica da sociedade moderna. Tocqueville dirá adiante que a preservação das garantias na democracia exige que os poderes sejam representantes da maioria sem, contudo, serem escravos de suas paixões. Ainda assim a resposta não soluciona o problema essencial colocado pelo conflito entre liberalismo e democracia no pensamento tocquevilliano: se a constituição liberal é vista como um mecanismo de equilí- 
O Império da Opinião: Espaço Público, Opinião Pública e a Legitimidade...

brios e garantias, como, em uma sociedade democrática, torná-lo infenso à interferência corruptora das paixões? Além disso, se a democracia ativa necessita da existência de um espaço público sempre aberto para colonizar o Estado pelo social, como tornar a opinião pública "desapaixonada" ou, dito de outro modo, como estabelecer limites legítimos para a ação no espaço público? Para compreendermos essa questão é preciso entender a interpretação de Tocqueville sobre a natureza da opinião pública no estado social democrático.

O tema da opinião pública é não só um dos mais constantes em $A$ Democracia na América, mais um dos conceitos mais mobilizados para caracterizar o movimento do estado social democrático. Tocqueville afirma que, tanto na América quanto na França, a opinião pública é o poder dominante. Contudo, na França, ela possui um caráter menos definido, sua influência sobre a formulação das leis é menos perceptível do que na América. E então, ele conclui que, na América, o exercício da opinião procede pelas eleições e pelas manifestações institucionais de autogoverno, enquanto na França, ela procede por meio das revoluções (Tocqueville, 1986a: 198). Assim, na América a opinião e os costumes democráticos nascem e se desenvolvem juntos na constituição da República, enquanto na França o caráter de ruptura que acompanha a conquista da liberdade política resulta em uma crise entre estado social e instituições ${ }^{11}$. Como Tocqueville apontará adiante, o momento em que se atribuem direitos políticos a um povo privado deles é sempre um momento de crise (Ibid: 359). Contudo, em ambos os casos, a natureza do poder da opinião, insiste Tocqueville, é sempre republicana: isso faz com que na França o exercício do poder real possa se parecer muito mais com uma república do que na América o poder do presidente possa se parecer com uma monarquia (Ibid: 198).

Ora, se a natureza da opinião pública é essencialmente republicana, ou seja, se ela foge à esfera do segredo e da razão de Estado e se exerce em um espaço expandido que articula Estado e Sociedade, ela é a dimensão por excelência na qual devem se articular participação política e motivações individuais. A participação na comunidade política democrática não se limita à mecânica institucional da eleição de representantes, mas ao exercício contínuo da "vida ativa cidadã". Essa relação fica muito clara quando Tocqueville distingue o patriotismo antigo e moderno.

Quando os povos são ainda simples em seus costumes e fechados na sua crença; quando a sociedade repousa docemente sobre uma ordem

DADOS - Revista de Ciências Sociais, Rio de Janeiro, vol. 61, nº 3, 2018 
Paulo Cassimiro

de coisas antiga, na qual a legitimidade não é contestada, vemos reinar o amor instintivo da pátria. Existe outro mais racional que esse; menos generoso, menos ardente talvez, mas mais fecundo e mais durável; este último nasce das luzes; ele se desenvolve com a ajuda das leis, ele cresce com o exercício dos direitos e termina, de qualquer forma, por se confundir com o interesse pessoal. Um homem compreende a influência que o bem-estar do país tem sobre ele próprio; ele sabe que a lei lhe permite contribuir para esse bem-estar, ele se interessa pela prosperidade de seu país, a princípio como uma coisa que lhe é útil, em seguida como sua própria obra (Ibid: 354 ).

Aquilo que Tocqueville caracterizará como sendo o "patriotismo instintivo da monarquia" em contraposição ao "patriotismo refletido da república" dá conta de algo mais do que o amor à pátria e descreve a própria natureza do vínculo entre os indivíduos e a comunidade política. Dizer que cada um é parte ativa do governo da sociedade na democracia americana significa dizer que a cidadania ativa produz um vínculo maior do que a identificação passiva com o pertencimento de nascença a uma determinada comunidade. É esse patriotismo refletido que garante a união da força da atividade social com a manutenção das garantias políticas. Assim, o cálculo da ação social tocquevilliana pressupõe a existência de uma sociedade ativa e sua penetração no âmbito de decisão da política. Contudo, essa equação se realiza de forma mais bem acabada na América por uma característica especial dessa sociedade. O problema da propriedade, colocado como centro da questão social na França revolucionária, está ausente da Revolução Americana. Na América, tendo a maioria um bem particular a defender, todos reconhecem por princípio o direito de propriedade. "No mundo político acontece o mesmo. Na América, o homem do povo concebeu uma alta ideia dos direitos políticos, pois ele tem direitos políticos; ele não viola os dos outros pois ele tem os seus"; e completa, adiante, afirmando que "o governo da democracia faz descer a ideia dos direitos políticos até o meio dos cidadãos, como a divisão dos bens coloca a ideia de propriedade em geral ao alcance de todos os homens (Ibid: 358). O conjunto de interesses que concorre para a "prosperidade geral" da sociedade - que não deve ser entendida, evidentemente, apenas como prosperidade econômica, se bem que esse critério exerça um papel fundamental na hierarquia dos interesses individuais - pressupõe, portanto, a vida ativa que se confunde com o problema da propriedade. Assim, "se no meio dessa confusão universal, não se conseguir ligar a ideia de direitos à de interesse pessoal que oferece como o único 
O Império da Opinião: Espaço Público, Opinião Pública e a Legitimidade...

centro imóvel do coração humano, o que vos restará para governar o mundo, senão o medo? (Ibid: 359).

Para Tocqueville - seguindo os desdobramentos do argumento de Constant, quando este relaciona o progresso da indústria e do comércio e a liberdade moderna - a vida ativa econômica é parte condicionante da vida ativa social; a vitalidade da comunidade política pressupõe um interesse conjunto no progresso da riqueza dos indivíduos ${ }^{12}$. Aqui, estamos em um universo teórico que ecoa todo o debate da economia política dos séculos XVIII e a primeira metade do XIX: a perspectiva de uma comunidade política em expansão no tempo - assim como está em expansão a tendência niveladora da democracia - encontra-se com a expectativa da expansão da atividade econômica moderna - o comércio, a indústria, a expansão do cultivo da terra, etc. A atividade social penetra todas as instâncias da vida humana na república democrática; ela caracteriza-se pela necessidade de uma opinião ativa e constante sobre os "negócios do Estado" (Ibid: 385). Essa conexão entre motivação individual e "patriotismo" é melhor observada na célebre ideia de "interesse bem entendido" desenvolvida por Tocqueville no segundo volume de A Democracia na América. Se o direito é a virtude tornada norma, na América a virtude obedece ao critério da utilidade. Nas palavras de Marcelo Jasmin,

Num mundo em que a virtude cívica dos antigos não pode mais viger e onde só pelo assentimento os indivíduos se interessam pelo público, o ímpeto inicial que dispara o ciclo da pedagogia tocquevilliana só poderia vir do cálculo e do interesse. De fato, afirmava Tocqueville, o que a prática comunitária produz é a transformação do cálculo em instinto, do interesse em escolha, da necessidade em virtude. Tal proposição reelaborava a teoria republicana de Montesquieu à luz da observação da experiência americana e atualizava, para a modernidade, o antigo princípio da virtude (JASMIN, 2000: 79)

O efeito da teoria do interesse bem entendido sobre os costumes políticos leva o cidadão a sacrificar uma parte de seu tempo ao interesse coletivo. $\mathrm{O}$ funcionamento dessa sociedade na qual todos reservam uma parte de seu tempo à atividade social resulta em um cálculo geral no qual a vida republicana e o interesse egoísta não se sobrepõem: a dimensão pública não sufoca a vida privada - como na república dos antigos - e o interesse não reduz a vida do indivíduo-cidadão à simples atividade do voto, criando uma barreira segura à expansão do despotismo democrático. Assim, Tocqueville, com o exemplo da República 
Paulo Cassimiro

Americana, oferece um modelo possível para a aparente incoerência entre vida republicana e liberdade moderna apresentada por Constant em sua Liberdade dos Antigos e dos Modernos.

A doutrina do interesse bem entendido produz grandes devotamentos; mas ela sugere cada dia pequenos sacrifícios; somente por ela não se fará um homem virtuoso; mas ela forma uma multidão de cidadãos regrados, temperantes, moderados, previdentes, mestres de si mesmos; e se ela não conduz diretamente à virtude da vontade, ela se aproxima dela sensivelmente por meio dos costumes. (...) Eu não temerei dizer que a doutrina do interesse bem entendido me parece, de todas as teorias filosóficas, a mais apropriada às necessidades dos homens de nosso tempo, e que vejo nela a mais poderosa garantia que lhes resta contra si mesmos (Tocqueville, 1986b: 175-6).

Assim, podemos ver como a ideia do interesse bem entendido redimensiona a relação entre uniformização dos caráteres resultado da democratização e o individualismo moderno, formulando uma "saída republicana" para o conflito entre igualdade e liberdade. Essa "teoria ética da ação política" de Tocqueville parte de um diagnóstico decisivo: a grande transformação do mundo moderno implica o redimensionamento da relação entre indivíduo e sociedade. O diagnóstico, evidentemente, não é uma originalidade tocquevilliana. Ele perpassa todo o espectro da filosofia política dos séculos XVIII e XIX. Contudo, ele rearranja os termos do debate de forma a demonstrar como a república moderna pode encontrar um meio termo entre liberdade individual e vida civil, entre ambições particulares e espaço público, entre interesse e opinião, evitando assim o risco da decadência da liberdade pública. Segundo Tocqueville, é no ponto onde se encontram a liberdade política e a vida civil ativa que a igualdade e a liberdade se confundem (Ibid: 137). O individualismo, ideia que expressa um sentimento novo, inerente à modernidade, é fruto da democratização. Ele nasce, segundo Tocqueville, do isolamento dos indivíduos da massa, criando uma "pequena sociedade" e, ao mesmo tempo, abandonando a "grande sociedade" (Ibid: 143).

Essa possibilidade criativa da vida social que emerge do fim da sociedade aristocrática pode ser um risco à saúde da república: o primado da "pequena sociedade" econômica ou da "pequena sociedade" religiosa em detrimento da "grande sociedade" política resulta necessariamente no esvaziamento do caráter republicano da democracia, alimentando a hidra do despotismo democrático. A ligação entre 
O Império da Opinião: Espaço Público, Opinião Pública e a Legitimidade...

interesse público e interesse individual que Tocqueville encontra na América, ou, dito de outra forma, a associação entre progresso da sociedade e progresso individual pode ser a solução para o impasse entre o primado da vida ativa individual e a necessária sobrevivência da vida ativa política. A teoria da ação social democrática de Tocqueville reencontra aqui o problema colocado por Constant em seu diagnóstico sobre a civilização do comércio e das luzes e o progresso da liberdade na Europa. É o próprio autor de A Democracia na América que reivindica uma "atualização" do argumento de Constant e seus contemporâneos, afirmando ter feito ver "como a ideia do progresso e a perfectibilidade indefinida da espécie humana são próprios das eras democráticas" (Ibid: 107). Assim, reconhecendo o caráter inevitável de uma forma de liberdade moderna que implica em um tipo de sociabilidade que anula a possibilidade da "liberdade dos antigos", Tocqueville reformula o debate da república moderna, procurando encontrar, a partir do exemplo da sociedade americana, a saída possível para o conflito entre liberalismo e democracia.

\section{CONCLUSÃO}

Jürgen Habermas, em um de seus primeiros trabalhos sobre a história e as transformações do conceito de espaço público ${ }^{13}$, afirma que este se estruturou nos séculos XVIII e XIX sustentado pela ideia de publicidade: o espaço público político (politische Öffentlichkeit) consiste na reunião de entes privados portadores de direitos (o indivíduo-cidadão) com finalidade pública. Dito de outro modo, o público que raciocina publicamente, com vistas a limitar e influenciar o Estado, tem em vista a manutenção da independência regulada publicamente da esfera privada - o espaço da vida econômica. "A esfera pública politicamente orientada adquire o estatuto normativo de órgão graças ao qual a sociedade mediatiza a si mesma através do poder de um Estado que responde às suas necessidades próprias" (HABERMAS, 2011: 84). Essa esfera pública burguesa, segundo Habermas, existe na intercessão entre a existência de um mercado liberalizado e a constituição de uma ordem política sustentada pelo reconhecimento constitucional do indivíduo-cidadão. Nesse contexto, o conceito de opinião pública exerce uma função essencial: a busca pela "melhor opinião" que concorre no espaço público visa adequar as decisões ao critério da racionalidade (Ibid: 64), realizando, assim, a união entre o plano da racionalidade, da justiça e da publicidade, que compõem o argumento da liberdade política no pensamento moderno ${ }^{14}$. Interpretada como um "desdobramento 
natural" do processo de Esclarecimento na constituição de uma sociedade que destrói as hierarquias estruturantes do Antigo Regime, a opinião obedece à lógica daquilo que o historiador Reinhardt Koselleck chamou de "democratização dos conceitos", ideia que descreve essa dimensão expansiva do espaço público no qual a "opinião" se exerce: ela não é mais apenas o objeto da avaliação dos filósofos e "hommes de lettres", mas antes um espaço de disputas no qual os conceitos políticos se transformam.

Todas essas transformações nos conduzem de volta ao problema da história: a sociedade liberal não pode ser pensada sem que o elemento da "verdade" sobre a boa ordem da comunidade seja atirado para o futuro. Na medida em que as condicionantes limitadoras da participação e da inclusão não apelam mais a elementos essenciais e estruturantes o pertencimento ao privilégio aristocrático ou à casta religiosa, por exemplo-, o liberalismo porta em seu seio o germe de sua transformação. A sociedade, emancipada da esfera do religioso e do Estado soberano, acredita na sua autoinstituição, e essa crença conduz à ideia de que a emancipação pode ser contínua, para além dos limites do estado atual da ordem social. É o conflito entre poder constituinte e poder constituído que retorna, permanecendo, doravante, aberto graças à liberdade do espaço público. A legitimidade da transformação encontra-se, assim, na promessa do futuro ou, como diz Marcel Gauchet, "no esforço para assegurar o futuro, nomear sua direção com certeza e subordinar sua produção ao trabalho de uma vontade plenamente consciente" (GAUCHET, 1985: 349). Dessa forma, o liberalismo passa a ter que lidar com essa dupla dimensão conflituosa de sua própria gênese: ele traduz a demanda pela expansão de garantias e direitos e, ao mesmo tempo, reconhece a necessidade da limitação institucional dessas mesmas garantias e direitos.

A democracia, entendida como transformação expansiva na lógica do liberalismo, é indissociável desse raciocínio processual. Como procuramos demonstrar, ao reconstruir alguns elementos do debate sobre a relação entre teoria liberal, democracia e opinião pública, a grande mudança no conceito de democracia só seria operada com a "revolução tocquevilliana" por meio da qual a democracia deixaria de ser interpretada apenas como uma forma de governo e passaria então a ser descrita como um processo de transformação social. O caráter contínuo e aberto do espaço público democrático é, segundo Tocqueville, a própria condição de sua sobrevivência enquanto forma republicana de 
O Império da Opinião: Espaço Público, Opinião Pública e a Legitimidade...

governo. A ideia do espaço público e da opinião pública como fundamentos da legitimidade liberal-democrática marcam o que Gauchet chamou de "condição transcendental do social": o reconhecimento de sua intransponível irredutibilidade a qualquer tipo de racionalização definitiva numa forma política que "realizará" a democracia - seja o Estado de classes ou a identidade entre nação/povo e Estado. Assim, o papel da ideia de opinião pública na teoria liberal está assentado, sobretudo, na crença da impossibilidade de uma resolução definitiva para o conflito entre sociedade civil e Estado.

Recebido para publicação em 26 de abril de 2016

Reapresentado em 8 de maio de 2018

Aprovado para publicação em 1 de outubro de 2018

DADOS - Revista de Ciências Sociais, Rio de Janeiro, vol. 61, n 3, 2018 


\section{Paulo Cassimiro}

\section{NOTAS}

1. Ver, respectivamente: HABERMAS, Jürgen (2011). Transformação Estrutural da Esfera Pública. São Paulo: Edunesp; BERLIN, Isaiah (1969). Four Essays on Liberty. Oxford: Oxford University Press; RAWLS, John (1999). “The Idea of Public Reason Revisited". In: Collected Papers. Edited by Samuel Freeman. Cambridge: Harvard University Press; MANIN, Bernard (1997). The Principles of Representative Governement. Cambridge: Cambridge University Press; URBINATI, Nadia (2014). Democracy Disfigured. Opinion, Truth and the People. Cambridge, Harvard University Press.

2. Para mais sobre a teoria política do jacobinismo, ver: BIGNOTTO, Newton (2010). As Aventuras da Virtude. As ideias republicanas na França do século XVIII. São Paulo: Cia. Das Letras; JAUME, Lucien (1989). Le discours jacobin et la démocratie. Paris: Fayard.

3. Para algumas referências teóricas na obra de Koselleck, ver as duas coletâneas de ensaios: Feres Júnior, João \& Jasmin, Marcelo. “História dos conceitos. Dois momentos de um encontro intelectual". In FERES JÚNIOR, João \& JASMIN, Marcelo (eds.) (2006). História dos conceitos: debates e perspectivas. Rio de Janeiro, Puc-RJ.

4. Para mais informações sobre as origens e os pressupostos teóricos da história do político ver o artigo introdutório de $\mathrm{LYNCH}, \mathrm{C}$. E. C. "D democracia como problema. Pierre Rosanvallon e a escola francesa do político". In: ROSANVALLON, P. Por uma História do Político. São Paulo: Allameda, 2010.

5. Sobre o uso do conceito de opinião pública nos primeiros anos da Revolução Francesa, ver: BAKER, 1990.

6. Para mais informações sobre a relação entre teoria do conhecimento, filosofia da história e teoria política na obra de Benjamin Constant, ver: CASSIMIRO, Paulo Henrique P (2016). O Liberalismo Político e a República dos Modernos: a crítica de Benjamin Constant ao conceito rousseauniano de soberania popular. Rev. Bras. Ciênc. Polit. [online]. 2016, n.20, pp.249-286.

7. Para a relação entre a teoria do progresso como fonte da liberdade e a teoria constitucional de Constant, ver, novamente: CASSIMIRO, Ibid.

8. Os "doutrinários" é o nome que se dá a um grupo de políticos e intelectuais franceses de importância central durante a Restauração (1814-1830) e a Monarquia de Julho (1830-1848) que buscaram conciliar as conquistas da Revolução com a existência de uma monarquia constitucional. Os doutrinários começam a ganhar relevância especialmente a partir de 1816, quando representam a principal força legitimista contra os ultrarrealistas na Câmara, defendendo as prerrogativas do rei contra o parlamento; contudo, é durante a Monarquia de Julho que os doutrinários estarão no centro do poder político francês, representados especialmente por seu principal nome, François Guizot, que ocupará quatro ministérios diferentes durante boa parte do reinado de Luiz de Orleães. Além de Guizot, outros representantes importantes do liberalismo doutrinário foram Royer-Collard, Charles de Rémusat, o Duque de Broglie e Victor Cousin. Para mais informações sobre a história do liberalismo doutrinário na França, ver: Craiutu, (2003); Nemo; Petitot, (2006); Rosanvallon, (1985).

9. Para mais sobre a relação entre autonomia do Estado e soberania moderna ver: ARAÚJO, Cícero (2013). A Forma da República. Da Constituição Mista ao Estado. São Paulo: Martins Fontes; FERREIRA, Bernardo (2013). “O Essencial e o Acidental: 
O Império da Opinião: Espaço Público, Opinião Pública e a Legitimidade...

Bodin (E Hobbes) e a invenção do conceito moderno de Constituição". Lua Nova, São Paulo, 88: 381-426.

10. As semelhanças entre a ideia de representação como mecanismo de constituição da razão pública e o modelo de representação virtual burkeana desenvolvido por Hannah Pitkin é evidente. Para mais, ver: PITKIN, Hanna (1967). The Concept of Representation. Berkley: University of California Press.

11. Para mais sobre as diferenças que as transformações políticas em direção ao estado social democrático apresentam entre França e Estados Unidos, ver: JASMIN, 2005; JAUME, 2008

12. Para mais informações sobre as relações entre Democracia e Interesse na obra de Tocqueville, ver: CASSIMIRO, Paulo H. P. (2018). "Alexis de Tocqueville e o liberalismo francês: continuidades e rupturas sobre o conceito de Democracia". Rev. bras. Ci. Soc. [online], vol.33, n.96; JASMIN, Marcelo Gantus. (2000). "Interesse bem compreendido e virtude em a Democracia na América". In: BIGNOTTO, Newton (org.) Pensar a República. Belo Horizonte: UFMG.

13. Optamos aqui por não utilizar o termo "esfera pública", tradução oferecida em português para o conceito Öffentlichkeit, e sim a tradução em francês, "espace public" ou espaço público, para que a conexão com a bibliografia e o debate sobre o liberalismo francês fique mais evidente.

14. Não temos espaço aqui para avançar na discussão sobre opinião pública no sentido habermasiano ou rawlsiano (em que pesem as diferenças específicas entre ambos) como racionalidade pública e opinião pública como a percepção média das opiniões do povo como coletividade, sentido que é dado por autores como Bernard Manin (1997) e Nadia Urbinati (2014). Contudo, remetemo-nos aqui a esta diferença, ressaltando a importância de compreendê-la em um futuro estudo sobre o tema. 


\section{Paulo Cassimiro}

\section{REFERÊNCIAS BIBLIOGRÁFICAS}

ARAÚJO, Cicero (2013). A Forma da República. Da Constituição Mista ao Estado. São Paulo: Martins Fontes.

BAKER, Keith Michael (1990). Inventing the French Revolution: essays on French political culture in the eighteenth century. Cambridge: Cambridge University Press.

BERLIN, Isaiah (1969). Four Essays on Liberty. Oxford: Oxford University Press.

BIGNOTTO, Newton (2010). As Aventuras da Virtude. As ideias republicanas na França do século XVIII. São Paulo: Cia. Das Letras.

BARBERIS, Mauro. Benjamin Constant. Rivoluzione, Constituzione, Progresso. Bologna: Il Mulino, 1988.

BINOCHE, Betrand (2012). Religion privée, opinion publique. Paris: J. Vrin.

CASSIMIRO, Paulo Henrique P.(2016). “O Liberalismo Político e a República dos Modernos: a crítica de Benjamin Constant ao conceito rousseauniano de soberania popular". Rev. Bras. Ciênc. Polit. [online]. n.20, pp.249-286.

(2018). "Alexis de Tocqueville e o liberalismo francês: continuidades e rupturas sobre o conceito de Democracia". Rev. bras. Ci. Soc. [online], vol.33, n.96.

CONSTANT, Benjamin (1822). Commentaire sur l'ouvrage de Filangieri (2 Tomes). Paris: P. Doufart Librarie.

(1997). Écrits Politiques. Textes choisis, présentés et annotés par Marcel Gauchet. Paris: Gallimard, 1998.

CRAIUTU, Aurelian. (2003). Liberalism under siege. The Political Thought of the French Doctrinaires. Laham: Lexiton Books.

DUSO, Giuseppe (2015). La Representación politica: génesis y crisis de um concepto. Buenos Aires: Jorge Baudino Ediciones.

FERES JÚNIOR, João; JASMIN, Marcelo. (2006) "História dos conceitos. Dois momentos de um encontro intelectual”. In FERES JÚNIOR, João \& JASMIN, Marcelo (eds.). História dos conceitos: debates e perspectivas. Rio de Janeiro, Puc-RJ.

FERRY, Luc; Renaut, Alain (2007). Philosophie politique. Paris: PUF.

FERREIRA, Bernardo (2013). “O Essencial e o Acidental: Bodin (E Hobbes) e a invenção do conceito moderno de Constituição". Lua Nova, São Paulo, 88: 381-426.

FONTANA, Biancamaria (1991). Benjamin Constant and the Post-Revolutionary Mind. New Haven: Yale University Press.

GAUCHET, Marcel (1985). Le désenchantement du monde. Paris: Gallimard.

GUIZOT, François (1880). Histoire des Origines du Gouvernement Representatif (2 Tomes). Paris: Didier et cie.

_ (1985). Histoire de la civilisation en Europe. Présenté par Pierre Rosanvallon. Paris: Hachette.

HABERMAS, Jürgen (2011). Transformação Estrutural da Esfera Pública. São Paulo: Edunesp. 
O Império da Opinião: Espaço Público, Opinião Pública e a Legitimidade...

JASMIN, Marcelo Gantus. (2005), Alexis de Tocqueville. A historiografia como ciência da política. 2o edição, Belo Horizonte, Rio de Janeiro, Editora UFMG, IUPERJ, 2005.

(2000). "Interesse bem compreendido e virtude em a Democracia na América". In: BIGNOTTO, Newton (org.) Pensar a República. Belo Horizonte: UFMG.

JAUME, Lucien (1989). Le discours jacobin et la démocratie. Paris: Fayard.

_ (1997). L'Individu Effacé ou le paradoxe du libéralisme français. Paris: Fayard.

(2008). Tocqueville. Les Sources aristocratiques de la liberté. Paris: Fayard.

KOSELLECK, Reinhart (1999). Crítica e Crise. Contribuição à Patogênese do Mundo Burguês. Rio de Janeiro: EdUerj: Contraponto.

(2006). Futuro Passado. Contribuição à semântica dos Tempos Históricos. Rio de Janeiro: Ed. PUC-Rio: Contraponto.

(2011) "Introduction and Prefaces to the Geschichtliche Grundbegriffe". Translated by Michaela Richter. Contributions to the History of Concepts Volume 6, Issue 1, Summer 2011:1-37. LYNCH, Christian (2010). "A democracia como problema. Pierre Rosanvallon e a escola francesa do político". In: ROSANVALLON, P. Por uma História do Político. São Paulo: Allameda.

MANENT, Pierre (1994). A Cidade do Homem. Lisboa: Instituto Piaget.

(1990). Histoire intellectuelle du libéralisme. Paris: Fayard.

MANIN, Bernard (1997). The Principles of Representative Governement. Cambridge: Cambridge University Press.

NEMO, Philippe; PETITOT, Jean (2006). Histoire du libéralisme en Europe. Paris: PUF.

PITKIN, Hanna (1967). The Concept of Representation. Berkley: University of California Press.

RAWLS, John (1999). "The Idea of public Reason Revisited". In: Collected Papers. Edited by Samuel Freeman. Cambridge: Harvard University Press.

STAËL-HÖLSTEIN, Germaine de (1797). Des Circonstances Actuelles quie peuvent Terminer la Révolution et des Principes qui doivent Fonder la Republique em France. Paris: Librarie Fischbacher, 1906.

(1858). Oeuvres de la Baronne de Staël-Holstein (3 Tomes). Paris: Lefèvre, 1858.

ROSANVALLON, Pierre (2000). La démocratie inachevée. Histoire de la souveraineté du peuple em France. Paris: Gallimard.

(2004). Le Modèle politique français. La société civile contre le jacobinisme de 1789 à nous jours. Paris: éditions du Seuil.

_ (1985). Le Moment Guizot. Paris: Gallimard.

(2010). Por uma História do Político. São Paulo: Alameda.

TOCQUEVILLE, Alexis de (1835). De la démocratie en Amerique I. Paris: Gallimard, 1986a. (1840). De la démocratie en Amerique II. Paris: Gallimard, 1986b.

(1856). O Antigo Regime e a Revolução. São Paulo: Martins Fontes, 2009.

URBINATI, Nadia (2014). Democracy Disfigured. Opinion, Truth and the People. Cambridge, Harvard University Press.

ZARKA, Yves Charles (dir.) (2002). Les fondements philosophiques de la tolérance. Tome I. Paris: PUF.

DADOS - Revista de Ciências Sociais, Rio de Janeiro, vol. 61, n 3, 2018 
RESUMO

O Império da Opinião: Espaço público, opinião pública e a legitimidade do político no argumento liberal francês

Este artigo explora o uso do conceito de opinião pública na constituição da linguagem liberal francesa do final do século XVIII e início do XIX a partir das obras de Benjamin Constant, Germaine de Staël, François Guizot e Alexis de Tocqueville. Nossa hipótese central é a de que o uso do conceito de opinião pública no argumento liberal transforma os limites da concepção revolucionária de representação como resultado da manifestação do povo como corpo soberano. A sociedade, enquanto lócus da legitimidade, exerce sua soberania não apenas através do mecanismo representativo, mas fundamentalmente por meio de um espaço público no qual se articulam e disputam narrativas pela melhor forma de organizar e conduzir o governo. Ao mesmo tempo, a expansão da opinião pública e os riscos de sua instabilidade colocam-na como um problema central para entendermos a relação entre liberalismo e democracia.

Palavras-chave: Opinião Pública; Espaço Público; Liberalismo; Constituição; Democracia.

\section{ABSTRACT}

The Empire of Opinion: Public space, public opinion and the legitimacy of politics in the French liberal argument

This article investigates the use of the concept of public opinion in the constitution of a liberal French language of the late eighteenth and early nineteenth centuries. In order to do this investigation the works of Benjamin Constant, Germaine de Staël, François Guizot and Alexis de Tocqueville are compared. Our central hypothesis is that these authors use of the concept of public opinion to define the people as a sovereign body. Society, as a locus of legitimacy, exercises its sovereignty not only through the representative mechanism, but fundamentally through a public space in which narratives are articulated and disputed by the best way of organizing and conducting government. At the same time, the expansion of public opinion and the risks of its instability put it as a central problem in understanding the relationship between liberalism and democracy.

Keywords: Public Opinion; Public space; Liberalism; Constitution; Democracy. 
O Império da Opinião: Espaço Público, Opinião Pública e a Legitimidade...

RÉSUMÉ

L'empire de l'opinion: Espace public, opinion publique et légitimité du politicien dans l'argument libéral français

Cet article explore l'utilisation du concept d'opinion publique dans la constitution du langage libérale française à la fin du XVIIIe siècle et le début du XIXe siècle d'après les œuvres de Benjamin Constant, Germaine de Staël, François Guizot et Alexis de Tocqueville. Notre hypothèse centrale est que l'utilisation du concept d'opinion publique dans l'argument libéral transforme les limites de la conception révolutionnaire de la représentation résultant de la manifestation du peuple tandis qu'organisme souverain. La société, comme lieu de légitimité exerce sa souveraineté non seulement à traves de la représentation, mais fondamentalement à traves de l'espace public dans lequel des récits sont articulés et contestés par la meilleur façon d'organiser et de diriger le gouvernement. En même temps, l'expansion de l'opinion publique et ses risques d'instabilité pose la comme un problème central dans la compréhension de la relation entre libéralisme et démocratie.

Mots-clés: Opinion publique ; Espace public ; Libéralisme ; Constitution ; Démocratie.

\section{RESUMEN}

El Imperio de la Opinión: Espacio público, opinión pública y legitimidad política en el argumento liberal francés

Este artículo examina el concepto de opinión pública en la formación del lenguaje liberal francés en el cambio del siglo XVIII hacia el XIX, desde B. Constant, G. de Staël, F. Guizot y A. de Tocqueville. La hipótesis sostienes que el uso liberal del concepto transforma los límites de la concepción revolucionaria de representación comprendida como resultado de la manifestación del pueblo como cuerpo soberano. La sociedad, como locus de la legitimidad, ejerce su soberanía no sólo a través del mecanismo representativo, sino fundamentalmente a traves de un espacio público en el que se articulan y disputan narrativas por la mejor forma de organizar y conducir el gobierno. Al mismo tiempo, la expansión de la opinión pública y los riesgos de su inestabilidad la sitúan como problema central para comprender la relación entre liberalismo y democracia.

Palavras-clave: opinión pública; espacio público; liberalismo; constitución; democracia

DADOS - Revista de Ciências Sociais, Rio de Janeiro, vol. 61, n 3, 2018 


\section{ERRATA}

Na página 659 , Onde se lia:

"http:/ /dx.doi.org/10.1590/001152582018156"

Leia-se:

"http://dx.doi.org/10.1590/001152582018170"

DADOS - Revista de Ciências Sociais (2018), vol. 61, nํㅜ: E3-E5 